\title{
4. Remembering the referendum with compassion
}

\section{FRANCES PETERS-LITTLE}

History is a bit like water; eventually it will find its own level.

Paul Keating, former Prime Minister of Australia ${ }^{1}$

In May 1967, Australian voters were asked to vote in a referendum to determine whether two references in the Australian Constitution, which discriminated against Aboriginal people, should be removed. ${ }^{2}$ The first reference was section 51, which stated that:

The Parliament shall, have the power to make laws for the peace, order, and good government of the Commonwealth with respect to, clause $\mathrm{xxvi}$, that the people of any race, other than the Aboriginal people in any State, for whom it is necessary to make special laws.

The second was section 127, which stated that:

In reckoning the numbers of the people of the Commonwealth, or of a State or other part of the Commonwealth, Aboriginal natives should not be counted.

When the votes were counted, up to 90.7 per cent of Australians voted 'Yes' in favour of removing the words, 'other than the aboriginal people in any State' in section 51 (xxvi) and the whole of section $127 .{ }^{3}$ It was the highest ever recorded in a federal referendum. Australians were obviously feeling compassionate.

It is now over 40 years since the Referendum, and it appears many historians remain undecided whether the amendments made to the Australian constitution

\footnotetext{
1 Hon Paul Keating interviewed by Frances Peters-Little for the Vote Yes for Aborigines documentary film, Sydney, 2006. The quote comes from the reply he gave me when I asked him 'Do politicians care about history?'

2 National Australian Archives, fact sheet, accessed 8 December 2009: <http://www.naa.gov.au/about-us/ publications/fact-sheets/fs150.aspx>

389.43 per cent of Australian voters voted Yes, however the figure often quoted is 90.77 per cent, but this figure excludes the 1.58 per cent of votes that were informal, cited in Williams 2000: 28.
} 
authorised by the Referendum were a complete waste of effort or indicated a stroke of genius by the campaigners. While some are convinced the Referendum brought about the necessary changes needed to liberate Aborigines from years of disenfranchisement and discrimination others insist the campaign did very little to change the political climate for Aborigines but instead left behind a trail of 'myths'. ${ }^{4}$ The main purpose of this paper is to discuss 'myths' (if myths they be) that have long been associated with the Referendum. The other purpose is 'not' to argue how effective the 1967 Referendum was, but to demonstrate why I think those who have a compassionate view of the 1967 Referendum are no less accurate in their representation of Aboriginal history than those who do not. To illustrate this point I will be referring to Vote yes for Aborigines ${ }^{5}$ a documentary film I wrote and directed in conjunction with SBS TV commemorating the 40th anniversary of the referendum as a part of the Unsettling Histories project. ${ }^{6}$

\section{Unsettling histories}

Having a compassionate and open mind for Indigenous storytelling was a key component in the Unsettling Histories project. As an Aboriginal historian, I have always been interested in collecting oral histories and sharing those stories in a number of ways, visually and aurally, that can be told and communicated by Aboriginal people. It was while working on the project with historian Ann McGrath from the Australian National University (ANU), and Margo Neale a senior curator from the National Museum of Australia (NMA), I came across a quote by American historian Peter Nabokov who wrote about Native American history that 'history was too important to be left to historians alone'. ${ }^{7}$ Since beginning the project I have referred to the Nabokov expression several times but I am yet to cite the original quote which I suspect is deeply rooted somewhere in European history. ${ }^{8}$ The suggestion that history was too important

\footnotetext{
4 Main proponents of the idea that the referendum brought about a monumental change to grant Aborigines new rights and freedoms are historians Jennifer Clark, Sue Taffe, Ann Curthoys, Gordon Briscoe and Jackie Huggins. Main opponents of the idea the referendum brought about a monumental change to grant Aborigines new rights and freedoms are Bain Attwood and Andrew Markus, Tim Rowse and John Gardiner-Garden. 5 Vote Yes for Aborigines is a 52-minute documentary film that revisits those involved with the 1967 Referendum and the social attitudes and influences that led to the event. Vote Yes for Aborigines went to air on SBS television on 27 May 2007.

6 The Unsettling Histories project was an Australian Research Council project that I had been a Chief Investigator with Ann McGrath and Margo Neale, from 2003 to 2007. Outcomes from the project were two films, a major photography exhibition and a publication.

7 Nabokov 2000: vi.

8 The term can also be cited in Jewish American Professor of Law and Legal Historian Eben Moglen's work on the Making History: Israeli Law and Historical Reconstruction who wrote just as war is too important to be left to the generals, history is too important to be left to the historians'. In this article, Moglen was paraphrasing a quote by former French Prime Minister George Clemenceau who said, 'war is too important to be left to the military'. Others who have used the term are Astronomer Donald Edward Osterbrock who titled his paper The View from the Observatory: History is Too Important to be Left to the Historians; and historians Sally Alexander, Raphael Samuels and Barbara Taylor in the 1970s.
} 
to be left to historians alone struck a chord with me as an Aboriginal historian reminding me of just how much Aboriginal history, since colonisation, has gone unobserved, forgotten or perhaps distorted by historians. ${ }^{9}$

The Unsettling Histories project focused on the various modes of Aboriginal historical practice and explored other modes outside of the written text, from films, exhibitions, photography, Indigenous painting to map-making, song and poetry art forms to sporting events and so forth. Drawing from alternative sources to record our histories is something that Maori scholar Linda Smith, is very much in favour of and stresses, and rightly so, that 'very few indigenous people if any, would have a need to perceive, practice or teach history the same way as the coloniser' ${ }^{10}$ One of the outcomes of the Unsettling Histories project was the volume of essays called Exchanging Histories, which I coedited with Ann McGrath and Ingereth Macfarlane. The Exchanging Histories volume commemorated the 30th edition of the journal Aboriginal History. Our intention was to bring together a collection that would investigate what the "history wars" was not, and that was to consider the ongoing practices of history-making and ideas about history by indigenous Australians' ${ }^{11}$ Other outcomes of the Unsettling Histories project were a series of public forums and university lecture series of the same name and three historical documentary films. One film was by McGrath called $A$ Frontier Conversation ${ }^{12}$ a 54-minute film that documents a unique collaboration between indigenous and white historians from Australia and North America, and I made the other two. The first of the films was called Our Community ${ }^{13}$ a 30-minute documentary made in conjunction with a photographic exhibition ${ }^{14}$ that shared the same title, and a one-hour documentary film called Vote Yes for Aborigines.

9 In his book Doing Oral Histories (2003) oral historian Donald Ritchie quoted Louis Gottschalk, in Understanding History who wrote "The numbers of historical writings are staggering but only a small part of what happened in the past was observed; and only a part of what was observed was remembered by those who observed it. Only a part of what was remembered was recorded; only a part of what was recorded has survived; only a part of what has survived has come to historians' attention; only a part of what has come to their attention is credible; only a part of what is credible has been grasped and only a part of what has been grasped can be expounded or narrated by the historian.' Gottschalk 1950.

10 Smith 1999: 28-29.

11 Peters-Little et al 2006: v.

12 'A Frontier Conversation raises more questions than answers - from cultural appropriation and copyright, to land rights, the role of language and art, and what history means to Indigenous communities in the current climate of cultural reclamation and survival.' Synopsis by Ronin Films cited at Ronin Films website, accessed 8 December 2009: <http://www.roninfilms.com.au/feature/545.html>

13 Our Community is a film that reveals that, despite the cultural diversity and the challenges before them, the people of the Walgett, Lightning Ridge and Sheepyard communities share a pride, passion, resilience and an inexorable spirit of 'belonging'. Throughout the film, past misconceptions about racial and economic divisions are clarified and benevolent bonds are celebrated.' Synopsis by Frances Peters-Little, cited at Ronin Films website, accessed 8 December 2009: <http://www.roninfilms.com.au/feature/516.html>

14 The Our Community: A Great Place to Be photographic exhibition was a joint project between The Australian National University's Australian Centre for Indigenous Histories, and the National Museum 
At the time we were making our films, other ANU historians such as Donald Denoon, Brij Lal and Tessa Morris-Suzuki from the Research School of Pacific and Asian Studies shared the view with us that historians have much to learn from working with other mediums such as journalism and literature. Morris-Suzuki says much academic writing is 'essentially unreadable, which is a pity, because a lot of it has something interesting to say' ${ }^{15}$ Lal pointed out that 'People are interested in lives and in human stories, rather than in abstract theories, a notion that has been lost to academia in the past 20 or so years ${ }^{\prime 16}$ and both Denoon and Lal argue that while 'archival, documented history can be accurate it cannot always be true in the way that fiction can' ${ }^{17}$ Also suggesting that historians may need to find 'truth' using other mediums is American historian Hayden White. White says more historians may wish to 'engage in the language of film, for not only is it a legitimate discourse in its own right, but visual representations of history have their own genius in the realms of landscapes, scenes, atmosphere, and such representations are not just more verisimilar, but also more accurate' ${ }^{18}$

Those involved with the Unsettling Histories project viewed the criticisms of our focus on filmmaking from some of our academic peers in the ANU as symptomatic of the prejudices that academics have against filmmakers in general. Historians often think that filmmakers are inclined to trivialise the past. Since making her film, which was her first, McGrath has challenged other historians on this issue, arguing that the fact they have been trained to deliver the results of their research only in text should not hinder them from recognising film as a genuine mode of historical practise and a major resource. ${ }^{19}$

Speaking as someone who has a documentary filmmaking background and became a historian later in life, I certainly object to the view that films are an inferior form of history making and believe films can be an extremely useful medium for historians to draw from and to engage with. One of the main reasons I enjoy making historical documentary films is because it is possible to interact directly with people on a one-to-one basis who can share their own stories, so that viewers get to hear another version of Aboriginal history and not just an

of Australia. It explores the concept of 'community' in multicultural rural Australia. Curated by Frances Peters-Little and Barbara Paulson, the exhibition toured regional New South Wales throughout 2005-2006. Photographers who participated in the exhibition were Sharon Aldrick, Ron Blake and Juno Gemes.

15 Morris-Suzuki 2004.

16 Lal 2004: 1-3.

17 Jan Borrie interview with Research School of Pacific and Asian Studies Professors Donald Denoon, Tessa Morris-Suzuki and Brij V Lal about their curious position as 'academics who write' - fiction, poetry and autobiography respectively, Canberra, March 2004, cited at: <http://rspas.anu.edu.au/qb/articleFile. php?searchterm $=5-1-3>$

18 White 1988 cited in Gunn 2006: 68.

19 McGrath 2009. 
academic interpretation. Another reason I like making historical documentary films is that it allows for room for a personal, compassionate and emotional reading of the past.

As an Aboriginal filmmaker, I am optimistic about the future of Aboriginal filmmaking. Not only do I hope to see more Aboriginal filmmakers teaching Aboriginal history to a more visual and technologically savvy youth, I also look forward to seeing more Aboriginal filmmakers recordings of our history; a particularly important issue since there are still many more Aboriginal people who make films than there are Aboriginal historians. American anthropologists Faye Ginsburg and Fred Myers regard the effect Aboriginal artists and filmmakers have had on understandings of Australian history over the past two decades as immense. In their words, the impact

Aboriginal filmmakers are making locally and overseas has already been significant and persistent, and that it is expanding despite the alarming political turn against gains made by indigenous Australians over the last decade, not only by right-wing politicians but intellectuals as well. ${ }^{20}$

\section{Making Vote Yes for Aborigines}

It was during the latter part of that particular decade (1997-2007) that Ginsburg and Myers refer to that I began writing the script for Vote Yes for Aborigines. John Howard, the then Prime Minister of Australia, was in the throes of putting together an Australian Citizenship Act, so it was a time I thought particularly fitting to be making a film about the history of Aboriginal citizenship. ${ }^{21}$ The film revisits those involved with the 1967 Referendum and the social and political attitudes and influences that led to the event. While writing the script I envisaged bringing together the voices of historians and politicians with those of Aboriginal and non-Aboriginal people who were part of the referendum campaign. Bringing together such a diversity of voices is something that I feel is sadly lacking in too many history books.

The chosen participants included former Australian Prime Ministers, the Honourable Paul Keating from the Australian Labor Party and the Honourable Malcolm Fraser from the Liberal Party. Other politicians were the former Federal Minister for Aboriginal Affairs Fred Chaney from the coalition government and current Australian Labor Party member and descendant of the Bundjalung tribe, Warren Mundine. Historians interviewed were Gordon Briscoe, John Maynard

\footnotetext{
20 Ginsburg and Myers 2007.

21 The 'Act sets out how you become an Australian citizen, the circumstances in which you may cease to be a citizen and some other matters related to citizenship', quoted from Commonwealth Consolidated Acts. Australian Citizenship Act 2007 - section 2a: <http://austlii.law.uts.edu.au/au/legis/cth/consol_act/ aca2007254/s2a.html>
} 
and Jackie Huggins, Bain Attwood, Ann Curthoys, Sue Taffe and Jennifer Clark. Others appearing in the film were those who had been involved with the 1967 Referendum campaign in one form or another such as Dulcie Flowers, Joyce Clague and Jimmy Little. Unfortunately, I had to edit out Jack Horner, Steve Larkin and Jon Altman because of technical problems and had to rely upon earlier footage of Faith Bandler whose husband Hans, was in serious ill health at the time we were shooting. ${ }^{22}$

The film opens with a voice-over of John Howard giving his speech on Australia Day in 2006. The words we hear from Howard are, 'Most nations experience some level of cultural diversity while also having a dominant cultural pattern running through them. In Australia's case, that dominant pattern comprises Judeo-Christian ethics, the progressive spirit of the Enlightenment and the institutions and values of British political culture. Its democratic and egalitarian temper also bears the imprint of distinct Irish and non-conformist traditions.' Howard's words set the tone of what to expect in the film. Then we cut to a number of vox-populis, asking people what they think it means to be an Australian citizen. The first response was from a group of Indian immigrants; one speaks and says, 'It must mean something, to be Australian; it must mean something.' An older white Australian male says, 'It's a lot of do with mateship.' A younger white male says, 'Yeah, it's good really. We are probably one of the luckiest countries in the world.' A 20ish couple, he is white and she is Asian, he says, 'I'm not really sure what it means to be an Australian.' She giggles. An older white woman says, 'I don't know.' A younger Aboriginal woman says, 'It's not really a question anybody really asks me, because we've been here for 40,000 years.' An older Aboriginal man says, 'Well I'm not an Australian citizen, I'm a citizen of the Wiradjuri nation.' And a very young Aboriginal boy with his face painted in ochre says 'I think about mostly the culture, and getting in and doing stuff.'

As difficult as it was for all my interviewees to find a definitive statement about what it meant to be an Australian citizen, they all agreed that a resoundingly high majority passed the 1967 Referendum. Where opinions begin to differ is on the question of whether the amendments made to the Constitution provided better outcomes for Aboriginal people. During the interviewing process it became clear that most of my interviewees were interested in discussing two main issues, Australian citizenship and the 'myths' of the referendum; in this chapter, I will focus on the latter.

22 Footage from Faith Bandler interview with Robyn Hughes, 1994 from the Australia Biography Series. 


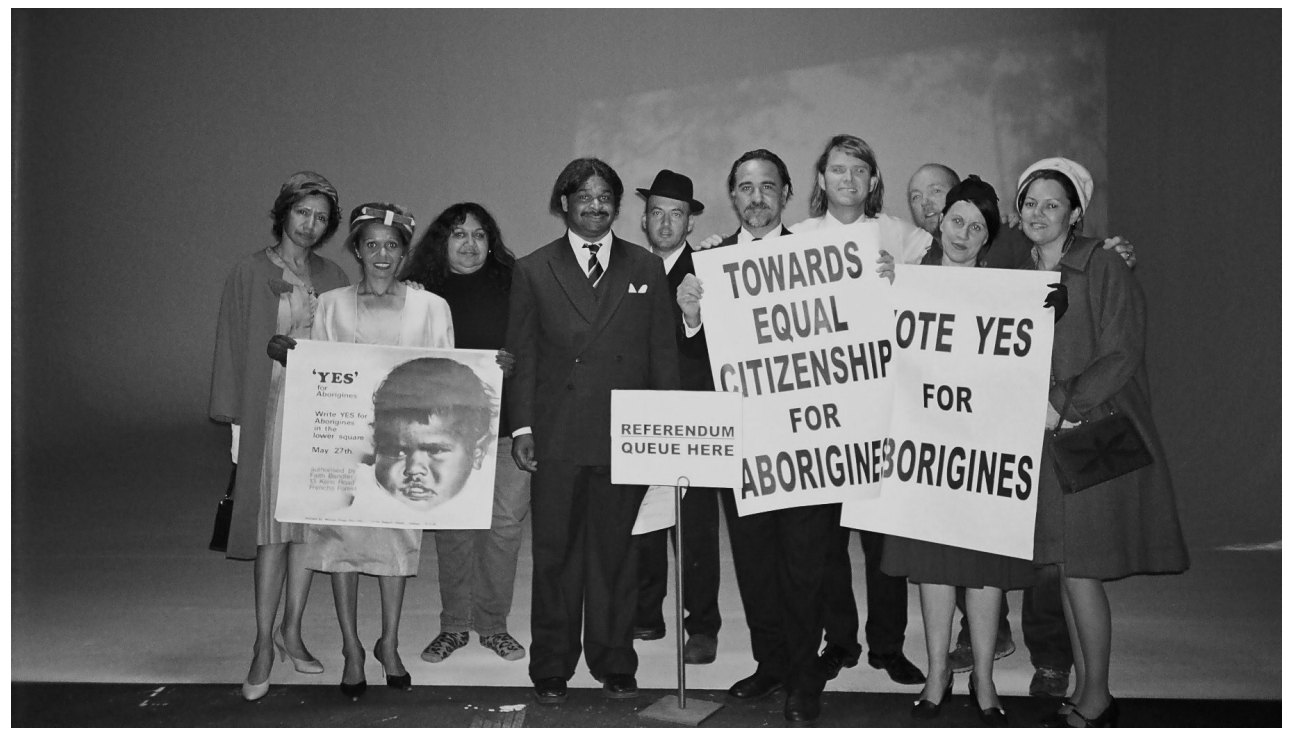

Fig 1. Cast and Crew for Vote Yes for Aborigines, Film Australia, September 2006 (From L-R Frances Williams, Esther Cohen, Frances Peters-Little, John Blair, Eman Ruggeri, Yani Demetriou, Sean Kennedy, Simeon Bryan, Cathy Payne, Suzy Ingram)

\section{The 'myths'}

While there are any number of hypotheses defining myths and/or mythologies, what I am referring to in this instance is the concept of 'myth' as an idea or a story that has been passed down from generation to generation that in time becomes thought of as fact or history. ${ }^{23}$ Although the term 'myth' conjures up notions of speculation and fantasy to some extent, what I intend to do is state why I think some 'myths' are more truthful than others based on the livedexperiences and the knowledges of Aboriginal people. It is just one small step towards telling a more complete history about Aboriginal people and the 1967 Referendum. The most common 'myths' since 1967 that have been contested by scholars in recent years are as follows;

(1) that the referendum gave Aborigines the right to vote,

(2) that it allowed Aborigines to be counted in the census, and

(3) that it gave Aborigines citizenship. ${ }^{24}$

23 Roland Barthes is perhaps the most well known French literary theorist, philosopher and critic who has written extensively on the subject of mythologies in his works in his book Mythologies, published in 1957.

24 Other 'myths' associated with the 1967 Referendum include the idea that it brought about wage equality, social security and maternity allowance and that it gave the Commonwealth government the right to make laws for the benefit of Aborigines, however I will only be addressing points (1) to (3). 


\section{The right to vote}

Proponents of the argument that the referendum did not give Aborigines the right to vote but that Aboriginal people already had that right are Bain Attwood and Andrew Markus. Attwood and Markus write 'Aboriginal people speak of the referendum in a way that scarcely has any historical verisimilitude', and have commented on a number of respected novelists, reputable historians and anthropologists who they say are mistaken. ${ }^{25}$ Adding to their case is one of Australia's leading constitutional lawyers George Williams who makes the point that Aboriginal people were allowed to vote before the 1967 Referendum and says that although 'changes to the constitution have been popularly seen as granting indigenous people equal rights, and in particular the right to vote, this is not correct' ${ }^{\prime 26}$ Though Attwood, Markus and Williams are in theory accurate, I argue that the operative word here is the 'rights' to vote and that there were many factors preventing Aboriginal people from voting before 1967 that changed after the referendum. ${ }^{27}$

Overlooking crucial details affecting Aboriginal people's rights to vote in his research brief, author John Gardiner-Garden wrote 'technically male Aboriginals had the right to vote since colonial times and by 1895 Aboriginal women in South Australia shared the same right'. ${ }^{28}$ He writes about polling booths stationed at Aboriginal reserves at Point McLeay and such, permitting Aboriginal men and women to vote in the first Commonwealth Parliament in 1901. Some of these rights were lost in the 1920s and 1930s, but by 1962, he argues, were returned when the Menzies-led Commonwealth government granted Aboriginal people the right to vote in Federal elections, which meant that all Aborigines living in Western Australia and Queensland could now vote. What is wrong with Gardiner-Garden's argument here is that he has assumed that because the Commonwealth government granted Aborigines voting rights, Aborigines thereby had complete liberty to vote at will, which of course is untrue. From Gardiner-Garden's perspective, one could easily be forgiven for thinking that Aborigines could freely make the choice to vote and that polling stations were accessible for Aborigines living in remote and rural regions, and that it was the responsibility of Aboriginal people to take full advantage of these rights.

In my interviews with several of the participants in my film, many offered clear accounts of how they and other Aboriginal people did not enjoy these 'rights' as

25 Attwood and Markus cite Tim Winton, Stuart McIntyre, Heather Goodall, Ann McGrath, Richard Broome and Barry Morris as some of the few who have misunderstood the results of the referendum.

26 Williams 2000: 28.

27 The changes are talked about by Joyce Clague and Jimmy Little who worked on a campaign to get Aborigines on the electoral roll after the 1967 Referendum.

28 Gardiner-Garden 2007. 
such. Aboriginal historian John Maynard who had been writing the biography of his grandfather Fred Maynard, at the time I interviewed him, emphasised how difficult it was to get Aboriginal people to vote in New South Wales. ${ }^{29} \mathrm{John}$ Maynard said,

Now we could vote in state elections, and most of us didn't know that, but my grandfather set out to inform Aboriginal people right throughout this state that they could vote. Now up on the north coast the Protection Board, certainly through the police, had hounded and harassed the Aboriginal activists of that particular period, they were under surveillance and threats were made against their own basically driving people like my grandfather and others who tried to encourage Aborigines to vote, to go underground..$^{30}$

Aboriginal activist and member of the Federal Council for Australian Aborigines and Torres Strait Islanders (FCAATSI) ${ }^{31}$ Joyce Clague stated that before she joined FCAATSI, encouraged by visiting activists like Jack Horner, ${ }^{32}$ the perception that she and others might wonder into town and vote at their own free will is false. Labor Party member, Warren Mundine, from Baryugil Mission, whose family did vote, says;

I don't think people understand what a different world we lived in; we tend to forget those days. The Aboriginal Protection Act in New South Wales was not abolished until two years after that referendum. So I suppose our equivalent were blacks in America you know, you go to the deep south and they were citizens of America, they had constitutional rights, they had voting rights but they could not exercise those rights, because if you turned up to vote you did so at considerable risk. ${ }^{33}$

The concept that Aboriginal people could exercise freedom of choice and had access to vote, as Gardiner-Garden implies, is also misleading considering that many Aboriginal people lived in remote areas and many, who spoke English as

29 Fred Maynard was born in 1879. A wharf labourer in Sydney Maynard established the Australian Aboriginal Progressive Association (AAPA) in 1925. The AAPA proposed for all Aboriginal families to receive inalienable grants of land and free entry to public schools. He was also strong opponent of the Aboriginal Protection Board.

30 John Maynard interviewed by Frances Peters-Little for the Vote Yes for Aborigines documentary film, Sydney, 2006.

31 Gordon Briscoe interviewed by Frances Peters-Little for the Vote Yes for Aborigines documentary film, Canberra, 2006. Briscoe's description of FCAATSI is that it 'developed out of a meeting of interested groups and began in Adelaide in 1958 as a private organisation of people from the churches, the trade unions, and a few articulate Aboriginal people who, some of whom were exempt, and some of whom were still wards of the State in which they lived'.

32 Joyce Clague interviewed by Frances Peters-Little for the Vote Yes for Aborigines documentary film, Sydney, 2006.

33 Warren Mundine interviewed by Frances Peters-Little for the Vote Yes for Aborigines documentary film, Sydney, 2006. 
a second language, did not have the necessary literacy and numeracy skills. For those who did have the skills, they had been expected to vote for candidates who had little or no regard for them or their needs according to Aboriginal singer Jimmy Little, who had a high public profile in the Australian music industry at the time. Little stated in my interview with him;

One of the glaring matters of voting was as I saw it back then, and still now today, is that a lot of our people thought, why should I vote for somebody I don't know, and somebody who doesn't know me and my needs, why should I put them in office? And so a good majority of Aboriginal people within the country as well as the city, had doubts about coming to the electorate roll and polling booths voting somebody in that they didn't know anything about. ${ }^{34}$

During the time of the referendum, Clague approached Little to use his status as a celebrity to appear on film to encourage the thousands of Aborigines who were yet to register on the Australian electoral roll. Following the referendum, Clague became instrumental in setting up polling booths in remote areas where Aborigines were yet to vote. She offers a brief scenario and says;

Thankfully, I was able to set up an education program for our people up there in the territory and I did it in the language of the Pitjantjatjara, and Warlpiri. Now they didn't have polling booth out at some of those places, you know, and you're looking at you know, three, four hundred people at a time. But I was able to say to the minister at the time, instead of doing this they can do the postal voting. But some of them were rejected because all they did was put their thumbprints on them or cross and, and then, someone else would do the rest of the filling for them you know, which was wrong. ${ }^{35}$

The 1967 Referendum was clearly a starting point for many Aboriginal people on a national level, it was not ideal and had numerous awkward beginnings, just as Clague described in the previous scenario, but opened a number of avenues for Aboriginal people to progress. The 1967 Referendum provided people like Little and Clague a new sense of hope, opportunity and freedom to take charge of their own affairs as a 'people', a nation even, and allowed them and other Aborigines to vote in ways that became meaningful to them and the rest of the nation.

34 Jimmy Little interviewed by Frances Peters-Little for the Vote Yes for Aborigines documentary film, Sydney, 2006

35 Joyce Clague interviewed by Frances Peters-Little for the Vote Yes for Aborigines documentary film, Canberra, 2006. 


\section{Being counted in the census}

In their attempt to dispel the 'myth' that the 1967 Referendum allowed Aborigines to be counted in the census, historians Tim Rowse and Len Smith emphasise that the Commonwealth Bureau of Census and Statistics counted Aborigines since $1911^{36}$ as they 'conceived them'. ${ }^{37}$ They argue that the removal of section 127 which stated 'In reckoning the numbers of the people of the Commonwealth, or of a State or other part of the Commonwealth, aboriginal natives should not be counted' had 'little if anything to do with the popular perception that the Australian Constitution was racially discriminatory'.$^{38}$ In my interview with him, Attwood does not say section 127 was discriminatory but said that,

The federal government was under considerable pressure to amend the two most negative sounding references, sections 51 and 127, but did not necessarily accept those aspects of the constitution as racially discriminatory, but were concerned how they had been perceived both nationally and internationally. ${ }^{39}$

Arguing the case that Aboriginal people were essentially disregarded by the Australian constitution are John Chesterman and Brian Galligan who write,

The constitutional treatment of Australia's Aboriginal people is cryptic and enigmatic. The commonwealth constitution that formally created the Australian nation and set up its federal system of government in 1901, mention Aboriginal people only twice, in its 128 sections. Moreover, both instances were by ways of exclusion. ${ }^{40}$

Joining Chesterman and Galligan in their criticism of the Australian constitution is Aboriginal human rights lawyer Larissa Behrendt who argues that to understand the Australian constitution at the time it was written is to realise some of the key assumptions of those who framed the constitution. She says that framers of the constitution held the belief, as white men, that they were superior to Aborigines who they mostly believed were fast on the way of become extinct. ${ }^{41}$

In regards to section 127 of the Constitution and the census collection on Aboriginal people, Rowse and Smith admit that they are mostly interested in how governments defined and collected data but were indifferent to lived-

\footnotetext{
36 Rowse and Smith 2008: 4.

37 What is meant by 'as the conceived them', is a matter of blood quantum, that is who was full-blood or half-caste, and so on. See Rowse 2002: 2.

38 Rowse and Smith 2008: 1.

39 Bain Attwood interviewed by Frances Peters-Little for the Vote Yes for Aborigines documentary film, Melbourne, 2006.

40 Chesterman and Galligan 1997: 58.

41 Behrendt 2000: 12.
} 
experiences of Aboriginal people and our knowledge of ourselves. As they say in their unpublished paper, 'The survival of the Aboriginal population', ${ }^{22}$ one of their main objectives were to identify a time during the 1960s when Australia may have ceased to have an Aboriginal population altogether and curious to why one still exists. ${ }^{43}$ While on the surface, it looks as if it could be interesting it falls short. A remarkably dull paper it provides readers with a detailed but dry recording of events and governmental definitions and practices carried out by the Bureau between 1961-1971. Much of it harking back to a time when it was not unusual to hear references made to Chinese, 'Negroes', Afghans and Aborigines as $1 / 2$ castes, $1 / 4$ castes or $3 / 4$ castes, subjected to the 'finer grading of their fractional descent', regardless of the fact that most Australians, particularly Indigenous Australians find this language extremely inappropriate and highly insensitive. ${ }^{44}$

Despite the obvious problems attached, the subject of blood capacity, 'race' and descent has been a topic that has fascinated Rowse for some time, making him somewhat the expert for more than a decade, and he has written about the subject in at least ten other publications, ${ }^{45}$ with which he writes with the same lack of insight ${ }^{46}$ and compassion. ${ }^{47}$ For me, the most redeeming feature of the Rowse and Smith paper is when they quote two well-known Aboriginal activists of the time. The first is poet Kath Walker ${ }^{48}$ and the other is Chicka Dixon. They quote Walker as having said:

Regarding the identification of an Aborigine surely the white man makes it very hard for himself in getting the census information by bringing in this caste business, quarter-caste and three-quarter-caste, etc. I notice

\footnotetext{
42 The paper is part of an ongoing project Rowse and Smith have been working on as part of their Australian Research Council Discovery Project since 2006 and part of a presentation given by Rowse and Smith for the History Program in the ANU seminar series, May 2007.

43 Rowse and Smith 2008: 2.

44 Rowse and Smith 2008: 3.

45 Rowse's interests in indigenous blood quantum can be found in the following books and papers; Rowse 1998, 2002, 2004, 2005, 2007, 2009a, 2009b. In addition, he is currently involved with working on another Australian Research Council Discovery Project with Smith called 'The Politics of Indigenous Enumeration in Australia Canada and New Zealand - a History, 2006-2009'.

46 Criticism of Rowse's lack of insight in the human element has been noted by Rick Rutjens who wrote, about Rowse's book, Nugget Coombs: A Reforming Life, 'It is a pity that Rowse does not capture the essence of this remarkable man in his 400-plus pages. Instead what he offers up is an amalgam of records, short snippets of facts trawled from the vast trove of Coombs's papers, departmental archives and other records. There is no sense of narrative, little exploration of the wider social and political environment in which Coombs lived, worked and thought.' Rutjens 2003.

47 Rowse has been accused of ignoring all the nastier parts of Australian history and for viewing Aborigines as a people who have come from a remarkably serene and pleasant landscape and have only themselves to blame for their disadvantages in Hal Wootten's speech at the launch of Tim Rowse's book Indigenous Futures, at the ANU Co-op Bookshop, 26 September 2002, Canberra, copy of speech cited at:

$<$ http://www.anu.edu.au/caepr/system/files/Publications/topical/woottenonrowse.pdf>

48 Kath Walker changed her name to Oodgeroo Noonucul in 1989. Her traditional name refers to the paperbark tree on her traditional land Stradbroke Island.
} 
he does not do this in the European world. Surely we can identify the Aborigine as one who identifies himself as an Aborigine - and we can well do without caste. ${ }^{49}$

Dixon was quoted in an article in the Sydney Morning Herald a few days before the 1967 Referendum as saying:

A 'yes' vote would end a long-standing insult to the Aboriginal people in the census.... We don't exist officially - yet we pay taxes. We don't exist - yet we are subject to a net of restrictive laws. We don't exist - yet we have to serve in the Army and accept the other responsibilities of citizenship. We don't mind accepting our responsibilities, but in return we want white Australia to recognise officially that we exist. We want to be human like everyone else. ${ }^{50}$

Both are statements that reflect how important it was for Aboriginal people to feel included in the census, regardless of whether the government said they were or not, and both are statements, which I believe, are a key to understanding why the referendum had such a huge impact upon the way Aboriginal thought about themselves.

Arguing against the view the 1967 Referendum had little or no bearing on Aborigines being counted in the census, is economist Jon Altman. In my interview with him, Altman stated that the 1967 Referendum technically recognised Aborigines to be counted in the 1971 census undefined by the state in terms of blood quantum. He says that while the 1971 figures were low, ${ }^{51}$ the census then allowed comparisons to be made between Aboriginal and nonAboriginal people, and says 'social indicators, like the things we hear about today, employment, income, housing, health status, etc., it was the availability of statistics on indigenous people in the census that allowed us to make those sorts of comparisons' ${ }^{52}$ In spite of this, such comparisons are somewhat artificial and unhelpful according to Rowse, who has come up with another suggestion for focusing on the socio-economic differences between Aboriginal and nonAboriginal people. He suggests that it is perhaps 'better to face up to indigenous

\footnotetext{
49 Kath Walker in Sharp and Tatz 1966: 13, quoted in Rowse and Smith 2008: 1.

50 Chicka Dixon statement cited in Attwood and Markus 1997: 116, cited in Rowse and Smith 2008: 10.

51 The figures were low compared to current figures because of many factors, for example, not everyone participated in the census. In addition, many Aboriginal people were yet to identify as Aboriginal because of the stigma attached or because they were prevented from doing so, or that many Aboriginal people were institutionalised or fostered out, or were not told they were Aboriginal.

52 Jon Altman interviewed by Frances Peters-Little for the Vote Yes for Aborigines documentary film, Canberra, 2006.
} 
socio-economic diversity and to discuss what differences of indigenous outcome are consistent with social justice and what differences of indigenous outcome are an affront to indigenous standards of fairness' ${ }^{53}$

Broaching the subject on an entirely different level from Rowse, Altman provides a historical background why he thinks the gap continues to exist. Altman says:

Indigenous people today are disadvantaged for a complex set of reasons. The first and more obvious is that they were dispossessed of their land and even though we've had land rights and native title that's returned land to some indigenous people, the vast majority of the indigenous population today still remain dispossessed. We also need to recognise that, indigenous people have had a long overdue history of neglect and there's been enormous under expenditure on indigenous people, and as Australian citizens and I think that this has left an enormous legacy. A combination of all these factors, mixed in with fundamental cultural difference for many indigenous groups, means that indigenous people really find it very hard to compete, in mainstream Australians society. ${ }^{54}$

As an Aboriginal filmmaker and historian, I am more drawn towards a compassionate understanding as to why so many Aboriginal people and our services are still under-resourced and our communities are largely disadvantaged and continue to use the statistics in some of my films, because I think they provide a key indication of the unequal status between Aborigines and nonAborigines in Australia today. ${ }^{55}$

\section{Granting citizenship}

Joining Rowse and Smith, Attwood and Markus, and Gardiner-Garden and other proponents in their quest to unravel the technicalities of the Australian constitution and reveal the 'myths' of the referendum is historian Melissa Nobles and political scientist James Jupp, who have recently argued that regardless of the misunderstandings surrounding the referendum, Aborigines were citizens before 1967. Nobles writes 'as a result of the 1948 Nationality and Citizenship Act, Aboriginal people, along with other Australians, became Australian citizens'. ${ }^{56}$ Jupp says, prior to Australia Day 1949, the status of citizens of Australia did not exist and that most persons resident in Australia were British subjects but became Australian citizens, including Aborigines, on

\footnotetext{
53 Rowse 2008.

54 Jon Altman interviewed by Frances Peters-Little for the Vote Yes for Aborigines documentary film, Canberra, 2006.

55 I have included statistics between Aboriginal and non-Aboriginal people in two of my films, Oceans Apart (1991) and Vote Yes for Aborigines.

56 Nobles 2008: 48.
} 
Australia Day 1949. ${ }^{57}$ Irrespective of their 'correct' observations, the belief that the 1967 Referendum gave Aborigines citizenship remains strong in the minds of many people.

When I had asked Bain Attwood, in my interview with him, why he thought so many supposed the referendum gave Aboriginal people citizenship rights Attwood thought that the idea that the referendum gave Aborigines citizenship arose from out of the campaign slogans and strategies that were used at the time. He stated:

Many people went to the polls on the 27th of May 1967 believing that by voting 'yes' you were going to bring about a national policy, federal control and citizenship rights for Aboriginal people. And if you look at the campaign material that is prepared, those matters are emphasised again and again. You look at posters and they say 'Right wrongs, vote yes', 'Vote yes for citizenship rights', many people, I think, voted in the referendum believing that they were granting Aboriginal people citizenship rights and that they were granting them the right to vote as part of a citizenship right.

Coming down strongly against the argument that the campaigners misled the Australian public is former member of the Federal Liberal Party (1972-1983) and Minister for Aboriginal Affairs Robert Ian Viner who says Attwood and Markus, and Gardiner-Garden were wrong to say the 1967 Referendum, or at least the post-1967 Referendum, was built on mythmaking. Viner is of the view that the realities of discrimination and disability that drove decades of Aboriginal activism were not myths but a result of successful politicking, ${ }^{58}$ helped along by some of the parliamentary 'back-benchers' at the time and William Wentworth, ${ }^{59}$ Gordon Bryant ${ }^{60}$ and Kim Beazley Senior. ${ }^{61}$ Viner also takes the compassionate view that the Australian people were persuaded to support a campaign that pushed for the rights for Aborigines to have 'equal citizenship' rights. Viner writes,

Paucity of income, education, housing, health, employment, cultural identity and recognition was a reality; the denial of freedom of movement was a reality; the denial of access to social services by entitlement was a reality. The denial of rights to vote and to equal justice before the courts were realities; the forced removal of people from their traditional lands

57 Jupp 2001: 119.

58 Viner 2007: 17-19.

59 William Wentworth, a member of the Liberal Party, was Australia's first minster in the Office of Aboriginal Affairs between 1968 and 1971 .

60 Gordon Bryant (3 August 1914 - 14 January 1991) was an Australian politician, a member of the Australian Labor Party, and was the Minister of Aboriginal Affairs between 1972 and 1973.

61 Kim Beazley Snr served in the Australian Labor Party for 32 years, from 1945 to 1977. 
and homes and the taking and occupation of traditional lands without compensation and the denial of ownership of traditional lands were all realities. None were myths' ${ }^{62}$

Others I have interviewed who have joined Viner in saying that the reason why the Australian people went to the polls that day believing they were helping to assist in giving Aborigines 'equal citizenship' rights are Sue Taffe, Jennifer Clark and Fred Chaney. According to Sue Taffe:

The referendum was about two clauses in the constitution. One clause was to do with Aboriginal people not being counted in the census, so they got rid of that, and the other clause was about giving the commonwealth the power to make special laws for Aboriginal people as a people, as a group. Now of course the commonwealth already had the power to make laws for Aboriginal people just as part of the Australian community, but the campaigners wanted this special power because they believed it was a little bit like affirmative action. They believed that it was necessary for laws to be made to counteract the damage of dispossession and to help Aboriginal people to, become a part of Australian society. So it was about citizenship if you like. ${ }^{63}$

Historian Jennifer Clark very clearly explains in an interview why the Australian public was less concerned about the politics or the legalities of the Australian constitution.

The government's role is to look at the constitution and legislation from a legal point of view. But the general public are not looking at the constitution from a legal point of view, they're looking at Aboriginal lives, they're looking at what Aborigines can do or can't do. They're looking at the fact that in some states of Australia at this time, some Aborigines could not marry without permission, could not move from place to place, in some places they were not in control of their own money. In some places, the mission or the employer would take the wages and the Aborigines were given rations instead so they did not have control over their own affairs. Some people began to argue that Aborigines were treated like children in this sense and were not able to determine their own lives; these were the issues that affected Aborigines in particular but seemed to be important to their supporters at the time. ${ }^{64}$

62 Viner 2007: 17-19.

63 Sue Taffe interviewed by Frances Peters-Little for the Vote Yes for Aborigines documentary film, Melbourne, 2006.

64 Jennifer Clark interviewed by Frances Peters-Little for the Vote Yes for Aborigines documentary film, Sydney, 2006. 
In my interview with Fred Chaney, the former Federal Minister for Aboriginal Affairs (1978-1980) and co-chair of Reconciliation Australia (2000-2005), Chaney said that it was easy to understand why the Australians believed Aborigines were not citizens of Australia because Aborigines were not living as other Australians. He said:

Well they were denied access often to education. They were denied access to social security, they were denied access to alcohol, which some might say in retrospect is probably, was now when we see the depredations of alcohol that's pretty sad. But the denial of basic civil liberties, the control over movement in many cases, the control over who you could marry, I mean the most amazing array of controls which in a sense destroyed the capacity of the Aboriginal community. I mean they were cut out of normal Australian life virtually. ${ }^{65}$

From the comments made by Taffe, Clark and Chaney, it becomes more understandable why Aboriginal people and the Australian public, and politicians even, went to the polls that day believing they were voting for the rights of Aborigines to become equal citizens, and were not just there because they were hoodwinked by the campaigners. That in effect people voted that day because they wanted to feel as though they were contributing towards a better future for Aboriginal people.

When I had posed the question 'What had they thought about their citizenship rights before and after the 1967 Referendum?' to a number of the Aboriginal interviewees for the film all had agreed on two things. They all said at some point that before the referendum that they did not think of themselves as Australian citizens as such, but as second-class citizens at the very most. However, after the referendum they thought they could at least have the choice to choose whether they wanted to think of themselves as Australian citizens. All the Indigenous interviewees, from Gordon Briscoe, Warren Mundine and Jimmy Little to the comments in the vox-pops in the first three minutes of the film, could now at least choose to think of themselves as Aboriginal or as Australians.

One of the first people I asked how he felt about being an Australian citizen before the referendum was historian Gordon Briscoe. In the interview, Briscoe

65 Fred Chaney interviewed by Frances Peters-Little for the Vote Yes for Aborigines documentary film, Sydney, 2006. 
explained to me how he and Charles Perkins, as residents of the Northern Territory, were governed by the Northern Territory Aborigines Welfare Act ${ }^{66}$ and became wards of the State. ${ }^{67}$

Aborigines wanted to seek a life outside of government control needed to apply to government for a special exemption. And this then gave them citizenship. We didn't want exemption from the Act so much as we wanted clauses changed in the Act which gave us the right to do things but still be Aborigines. We didn't particularly want an exemption, but we wanted to do things, we wanted the right to associate with one another, we wanted the right to become union members. We wanted the right to own property outside, as Aborigines. These are the kinds of things that we wanted changed to allow us to do that. ${ }^{68}$

Aboriginal politician Warren Mundine also gave an account what life was like for him growing up prior to the 1967 Referendum.

Aboriginal people of my generation and older tell you stories with the mission managers and the welfare officers just turning up and walking into your house, checking you out to see if you were clean; if you cleaned your teeth, your ears were clean, your hair, made sure your clothes were ironed, made sure you were dressed, your shoes were polished, the house was clean the washing and ironing was done the lawn was mowed and all that type of thing; people think they're an exaggeration, they can't believe that - that people were - you know, were treated like children, and that's not an exaggeration, that's a fact, that's how people were treated. ${ }^{69}$

Popular Aboriginal entertainer Jimmy Little, who was born near the Victorian border but reached the heights of his career in the 1960s, said that his chance to break free of a second-class citizenship, was to leave home and move to Sydney, but for his father, it meant he had to apply for an exemption certificate.

People of my generation knew that for a long time we were second class citizens, but felt the need to move to the cities. So while we were

66 The Federal government passed the Northern Territory Aboriginals Ordinance in 1911. The Chief Protector is made the legal guardian of every Aboriginal and 'half-caste' child under 18 years old. Any Aboriginal person can be forced onto a mission or settlement and children can be removed by force.

67 In 1957, the Northern Territory Welfare Ordinance 1953 comes into operation thus making all Aborigines wards of the state, meaning that the state, or territory held authority over the legal rights of Aboriginal people on matters that white Australians could enjoy freely, that is the right to drink alcohol or enter into a hotel was one of the rights denied.

68 Gordon Briscoe interviewed by Frances Peters-Little for the Vote Yes for Aborigines documentary film, Canberra, 2006.

69 Warren Mundine interviewed by Frances Peters-Little for the Vote Yes for Aborigines documentary film, Sydney, 2006. 
coming together as different tribes in a modern sense we had to deal with another tribe, urban tribes if you like. But for my poor old dad god-bless him, he had to have what we termed back then, a dog collar. He had to have a permit to go onto a mission and off the mission, and things of that nature. ${ }^{70}$

When I had asked them how did they feel about their status as Australian citizenship 40 years after the referendum, their answers varied. Briscoe said:

I'm an Australian citizen um, in some sense, in a partial way. I accept that the fact that there are governments that have platitudes about democracy. But those democratic values are not the kind of democratic values that I have which are an international type. I accept that I have some citizenship in Australia but I don't agree with the kind of treatment that white Australia and its governments and Britain have allowed the Australian governments to denude us from our real heritage. Our heritage is built on what white people think. Not what we think. And this is tantamount to the kind of contempt that Australian government, State and Federal have had for political organisations that deal with Aboriginal rights.

Mundine's response to the question did he feel like he was an Australian citizen was:

Well I- I um.. it's- it's beyond me, it's bigger than me um.. I've um.. I've received the benefits of that, you know, my lifestyle ah.. my achievements in life was- was done because of the sacrifices of people that come before me and the people who struggled for the last two hundred years ah.. the people that we know so well about like the Pearl Gibbs and the- and the ah.. William Ferguson's and many other people; the- the Tent Embassy, you know, the people in the 20s and 30s who rallied for citizenship rights'.71

Little says:

I'm Australian made, in every sense of the word. But before me, I was the first sunrise people, the same blood that runs through the veins of me today, ran through my first grandfather, my first grandmother. And that's centuries ago. So, how can I not be proud of being a warrior in modern times from the early times on this planet. It's just that in our time frame, all of us, we have to make a contribution, we have to take

70 Jimmy Little interviewed by Frances Peters-Little for the Vote Yes for Aborigines documentary film, Sydney, 2006.

71 Warren Mundine interviewed by Frances Peters-Little for the Vote Yes for Aborigines documentary film, Sydney, 2006. 
our share of the pie, take our credits where credit is due. And those of us who take too much pie, we have to pay the consequences. So it's a matter of proportion, and it's a matter of trust, it's a matter of lacking greed, it's a matter of having passion. ${ }^{72}$

\section{Conclusion}

As an Aboriginal filmmaker and historian, I very often make films about the things I write about and vice-versa. For the Unsettling histories project, for example, I wrote a paper called The community game: Aboriginal self-definition at the local level, about the Aboriginal community of Walgett in 2000 and then made a film called Our community five years later. In the case of the 1967 Referendum, I made the film Vote yes for Aborigines first, and decided to write about the subject later. In terms of writing this chapter, what I set out to do was discuss the 'myths' associated with the referendum and to demonstrate why I think a compassionate view of history is vitally important to understanding Aboriginal history as a whole. In terms of myths, in this chapter I have argued that while in theory the referendum did not grant Aborigines the 'right' to vote, Aborigines did not enjoy the same rights and access, but that the referendum had made it easier for them to vote or at the very least, made the idea of voting more meaningful to them. What I have argued in the case of being counted in the census is that the 1967 Referendum made it possible for Aborigines to be counted in the census undetermined by government terms, and that this had made a major break through in the ways Aborigines began to identify their needs and socio-economic status. Finally, I have argued that while changes to the Australian constitution did not technically give Aborigines citizenship, what the referendum did achieve, was perhaps for the first time since colonisation, Aborigines on a national level, could now have a choice to consciously and publicly accept or reject what white Australia had offered them in terms of their status as Australians.

In terms of making the film, it was not, however, until my last interview for the Vote yes for Aborigines documentary, with the former Prime Minster of Australia, Paul Keating that I decided how I was going to pull the film together and, consequently, how I would write about it. The question I posed to Keating at the time was, 'did politicians care about history?' his reply was that 'history was a bit like water, that eventually it would find it own level', 'it' meaning, the truth, or at least, what people would end up believing to be the truth. It is with this view in mind that I have argued that one cannot truly understand the 1967 Referendum without understanding the 'myths' associated with it and

72 Jimmy Little interviewed by Frances Peters-Little for the Vote Yes for Aborigines documentary film, Sydney, 2006. 
why they have lasted for so long. While it is understandable for historians to try to 'level the waters' that Keating talks about by writing about the referendum in terms of abstract theories, I believe that we have so much more to learn from the 'myths' associated with it, and how we might remember the 1967 referendum, with compassion, in the future.

\section{References}

Bain Attwood and Andrew Markus 1997, The 1967 Referendum: or when Aborigines did not get the Vote, Aboriginal Studies Press, Canberra.

Behrendt, Larissa 2000, The 1967 Referendum: 40 Years on, University of New South Wales Press, Sydney.

Chesterman, John and Brian Galligan 1997, Citizens without Rights: Aborigines and Australian Citizenship, Cambridge University Press, Melbourne.

Gardiner-Garden, John 2007, 'The 1967 Referendum-history and myths', Research Brief no. 11 2006-07, Parliamentary Library, Parliament of Australia, Canberra, accessed 10 May 2010: <http:/www.aph.gov.au/library/pubs/ rb/2006-07/07rb11.htm\#myths>

Ginsburg, Faye and Fred Myers 2006, 'A history of indigenous futures: accounting for indigenous art and media', Aboriginal History 30: 95-110.

Goot, Murray and Tim Rowse 2007, Divided Nation? Indigenous Affairs and the Imagined Public, Melbourne University Press, Melbourne.

Gottschalk, Louis 1950, Understanding History: a Primer of Historical Method, Alfred A Knopf, New York.

Guynn, William H 2006, Writing History in Film, Routledge, New York.

Jupp, James 2001, The Australian People: an Encyclopaedia of the Nation, its People and their Origins, Cambridge University Press, Melbourne.

Lal, Brij 2004, 'Creative endeavours', Quarterly Bulletin 5(1), accessed 10 May 2010: <http://rspas.anu.edu.au/qb/articleFile.php?searchterm=5-1-3>

McGrath, Ann 2009, 'Must film be fiction?', Griffith Review 24, Griffith University, accessed 10 May 2010: <http:/www.griffithreview.com/edition24-participation-society/222-essay/659.html>

Morris-Suzuki, Tessa 2004, 'Creative endeavours', Quarterly Bulletin 5(1), accessed 10 May 2010: <http://rspas.anu.edu.au/qb/articleFile. php?searchterm $=5-1-3>$ 
Nabokov, Peter 2000, A Forest of Time: American Indian Ways of History, Cambridge University Press, Melbourne.

National Australian Archives, fact sheet, accessed 8 December 2009: <http:// www.naa.gov.au/about-us/publications/fact-sheets/fs150.aspx>

Nobles, Melissa 2008, The Politics of Official Apologies, Cambridge University Press, Cambridge, USA.

Peters-Little, F, A McGrath and I Macfarlane (eds) 2006, Exchanging Histories, Aboriginal History 30.

Ritchie, Donald 2003, Doing Oral History, Oxford University Press, Oxford.

Rowse, Tim 1998, White Flour, White Power: from Rations to Citizenship in Central Australia, Cambridge University Press, Melbourne.

- 2002, 'Towards a history of Indigenous statistics in Australia', in Assessing the Evidence on Indigenous Socioeconomic Outcomes: a Focus on the 2002 NATSISS, Boyd Hunter (ed), ANU E Press, Canberra: 1-11.

- 2004, 'Indigenous autobiography in Australia and the United States', Australian Humanities Review 33: 1-12.

- (ed) 2005, Contesting Assimilation, API Network, Perth.

— 2008, "The politics of "the gap" in Australia and New Zealand', a paper presented in the Centre for Aboriginal Economic Policy Research, Australian National University, 28 May 2008, accessed 10 May 2010: <http://www.anu. edu.au/caepr/system/files/Seminars/presentations/Rowse_Gaps.pdf>

Rowse, Tim and Len Smith 2008, 'The Survival of the Aboriginal Population', unpublished paper, Canberra.

- 2009, 'Official statistics and the contemporary politics of Indigeneity', Australian Journal of Political Science 44(2): 193-211.

- 2009, "The ontological politics of "closing the gaps" and official statistics', Journal of Cultural Economy 2(1-2): 33-48.

Rutjens, Rick 2003, 'Tim Rowse, Nugget Coombs: a Reforming Life (book review)', Journal of Australian Studies 77: review of books.

Sharp, IG and CM Tatz (eds) 1966, Aborigines in the Economy, Jacaranda, Brisbane.

Smith, Linda Tuhiwai 1999, Decolonizing Methodologies: Research and Indigenous Peoples, University of Otago Press, Dunedin. 
Viner, Hon Ian 2007, 'Are Aboriginal and Torres Strait Islanders on the road ahead or the road back?', Australian Indigenous Law Review 11, Special Edition: 17-19.

White, Hayden 1988, 'Historiography and historiophoty', American Historical Review 93(5): 193-199.

Williams, George 2000, A Bill of Rights for Australia, University of New South Wales Press, Sydney. 